\title{
Voltametric Determination of Zoledronic Acid in a Pharmaceutical Formulation
}

\section{Farmasötik Bir Formülasyonda Zoledronik Asidin Voltametrik Tayini}

\author{
(D) Abdulaziz AMRO1*, (D) Samer RATROUT², (D) Fadi ASFOUR² \\ 1Al-Ahliyya Amman University Faculty of Pharmacy, Department of Pharmaceutical Sciences, Amman, Jordan \\ 2Hikma Pharmaceuticals, Amman, Jordan
}

\section{ABSTRACT}

Objectives: The aim of this study is to study the electroactivity of zoledronic acid (ZOL), optimize the parameters affecting voltametric analysis of ZOL, and make a comparison between voltametric methods used to assay ZOL.

Materials and Methods: Three voltametric methods, cyclic voltammetry (CV), square wave voltammetry (SWV), and differential pulse voltammetry (DPV), were used to determine the concentrations of $\mathrm{ZOL}$ solutions $\left(0.25^{-1} .2 \mathrm{mg} \cdot \mathrm{mL}^{-1}\right)$. Britton-Robinson universal buffer solutions (BRB) were used as supporting electrolytes with a glassy carbon working electrode.

Results: The calibration plots were linear in the range from 0.20 to $1.2 \mathrm{mg} \cdot \mathrm{mL}^{-1}$ for differential DPV and $\mathrm{CV}$ and from 0.09 to $1.2 \mathrm{mg} \cdot \mathrm{mL}^{-1}$ for $\mathrm{SWV}$. DPV showed the highest correlation coefficient $R^{2}$ value of 0.993 and the lowest limit of detection (LOD) of $37.2 \mu g . \mathrm{mL}^{-1}$. Furthermore, DPV exhibited the highest precision with the lowest relative standard deviations (RSD) values. For a commercial product of ZOL, DPV showed the best accuracy and precision with $102.32 \%$ recovery and $2.88 \%$ RSD.

Conclusion: ZOL is an electroactive compound. The $\mathrm{pH}$ of the BRB supporting the electrolyte is important for ZOL electroactivity. DPV is the recommended method for voltametric analysis of ZOL because of its high-performance regarding accuracy, precision, and LOD compared with other studied methods.

Key words: Zoledronic acid, electroanalytical methods, voltammetry, pharmaceutical compound analysis

öz

Amaç: Bu çalışmanın amacı zoledronik asidin (ZOL) elektroaktivitesini incelemek, ZOL'nin voltametrik analizini etkileyen parametreleri optimize etmek ve ZOL'yi test etmek için kullanılan voltametrik yöntemler arasında bir karşılaştırma yapmaktır.

Gereç ve Yöntemler: ZOL solüsyonlarının konsantrasyonlarını $\left(0,25^{-1}, 2 \mathrm{mg} \cdot \mathrm{mL}^{-1}\right)$ belirlemek için üç voltametrik yöntem, dönüșümlü voltametri (CV), kare dalga voltametri (SWV) ve diferansiyel puls voltametri kullanıldı (DPV). Britton-Robinson evrensel tampon çözeltileri (BRB) destekleyici elektrolitler olarak camsı karbon çalışma elektrodu ile kullanıldı.

Bulgular: Kalibrasyon grafikleri, DPV ve CV için 0,20 ile 1,2 mg. $\mathrm{mL}^{-1}$ aralığında ve SWV için 0,09 ile 1,2 $\mathrm{mg}_{\mathrm{mL}} \mathrm{m}^{-1}$ aralığında doğrusaldı. DPV ile en yüksek korelasyon katsayısı $R^{2}$ değeri 0,993 ve en düşük saptama sınırı (LOD) 37,2 $\mu g \cdot \mathrm{mL}^{-1}$ elde edildi. Ayrıca, DPV, en düşük bağıl standart sapma (RSD) değerleriyle en yüksek hassasiyeti sergilemiștir. ZOL'nin ticari bir ürünü için DPV, \%102,32 geri kazanım ve \%2,88 RSD ile en iyi doğruluğu ve hassasiyeti gösterdi.

Sonuç: ZOL, elektroaktif bir bileşiktir. Elektroliti destekleyen BRB'nin pH değeri, ZOL elektroaktivitesi için önemlidir. DPV, incelenen diğer yöntemlerle karşılaştırıldığında doğruluk, hassasiyet ve LOD ile ilgili yüksek performansı nedeniyle ZOL'nin voltametrik analizi için önerilen yöntemdir.

Anahtar kelimeler: Zoledronik asit, elektroanalitik yöntemler, voltametri, farmasötik bileşik analizi

\footnotetext{
*Correspondence: abdulazizamro@yahoo.com, Phone: 966590990428, ORCID-ID: orcid.org/0000-0002-0490-9284

Received: 17.04.2020, Accepted: 14.07.2020

๑Turk J Pharm Sci, Published by Galenos Publishing House.
} 


\section{INTRODUCTION}

Zoledronic acid (ZOL), which is known by the IUBAC name (1-hydroxy-2-imidazole-1-yl-phosphonoethyl) phosphonic acid (Figure 1), is a bone resorption inhibitor compound used principally for the treatment osteoporosis, Paget's bone disease, and malignant hypercalcemia. ${ }^{1-3}$ The pharmacologic action of ZOL bisphosphonate is to inhibit bone resorption by acting on osteoclasts or on osteoclast precursors to inhibit osteoclastic activity and skeletal calcium release induced by tumors. $^{2}$

Several methods have been used for analysis of pharmaceutical compounds, such as chromatographic, spectroscopic, and electrochemical methods. Most standard methods essentially rely on chromatography, especially high-performance liquid chromatography (HPLC). On the other hand, chromatographic methods have high operation and instrumentation costs; furthermore, chromatographic methods are not green analytical methods because of the large amount of organic solvents used in them.

Electroanalytical methods are better alternatives to spectroscopic and chromatographic methods, because they offer advantages such as low instrumentation and operation costs, short analysis times, and simplicity.

Electroanalytical methods such as voltametric, potentiometric, and polarographic methods have been widely applied to pharmaceutical compound analysis. ${ }^{4-8}$ These techniques show reliable results with respect to accuracy, precision, sensitivity, and selectivity. 4.5

Several research studies have worked on ZOL determination. Most of these studies used HPLC to study ZOL in different media, such as pharmaceutical products, ${ }^{910}$ human urine and blood plasma, ${ }^{11}$ human bone, ${ }^{12,13}$ and murine bone. ${ }^{14}$ Legay et al. ${ }^{15}$ developed a radioimmunoassay method for $\mathrm{ZOL}$ determination in human serum, plasma, and urine. Amin et al. ${ }^{16}$ developed a switchable fluorescence probe for ZOL determination in human serum. In the present work, we study the electroactivity of ZOL and the parameters affecting voltametric analysis of ZOL, such as the working electrode and supporting electrolyte. In addition, we establish a comparison between voltametric methods used for ZOL assay in a pure pharmaceutical formulation and the final product solution.

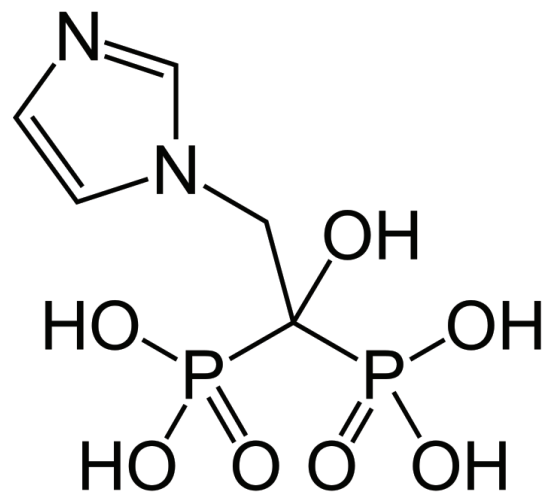

Figure 1. Structure of zoledronic acid

\section{MATERIALS AND METHODS}

\section{Materials}

Commercial product of ZOL (ZOL HIKMA ${ }^{\circledast} 4 \mathrm{mg} / 5 \mathrm{~mL}$ concentrate for solution for infusion) and ZOL standard material were provided by Hikma pharmaceutical company (Jordan). Potassium nitrate $\left(\mathrm{KNO}_{3} \mathrm{ACS}\right.$ reagent) was from Fluka, sodium sulfate anhydrous $\left(\mathrm{Na}_{2} \mathrm{SO}_{4}\right)$ was from Janssen Chemica, and citric acid anhydrous was from Al-Saggaf pharma.

Britton-Robinson universal buffer solutions (BRB) pH (2.1-11.6) were prepared by mixing certain amounts of boric acid, acetic acid, and phosphoric acid, then sodium hydroxide $(0.20 \mathrm{M})$ was used to adjust the $\mathrm{pH}$ of the mixture.

Phosphate buffer $\mathrm{pH} \quad 6.8 \quad\left(\mathrm{NaH}_{2} \mathrm{PO}_{4} / \mathrm{H}_{3} \mathrm{PO}_{4}\right)$ supporting electrolyte was prepared by dissolving $24 \mathrm{~g}$ of $\mathrm{NaH}_{2} \mathrm{PO}_{4} \times \mathrm{H}_{2} \mathrm{O}$ in $800 \mathrm{~mL}$ of deionized water, and then $\mathrm{pH} 6.8$ was reached by adding $85 \% \mathrm{H}_{3} \mathrm{PO}_{4}$. After that, deionized water was used to complete the volume to $1.0 \mathrm{~L}$.

Sodium citrate buffer $(\mathrm{pH} 3)$ supporting electrolyte solution was prepared by mixing $42.5 \mathrm{~g}$ of citric acid with $800 \mathrm{~mL}$ of deionized water, and then $\mathrm{pH} 3$ was reached by adding $\mathrm{NaOH}$ $20 \% \mathrm{w} / \mathrm{v}$ to the solution.

\section{Standard ZOL solutions}

Standard stock solutions of ZOL were prepared by dissolving a certain quantity of standard ZOL powder in supporting electrolyte solutions. Working solutions of ZOL standard were prepared by diluting the standard stock solution with the supporting electrolyte. ZOL HIKMA ${ }^{\circledast} 4 \mathrm{mg} / 5 \mathrm{~mL}$ concentrate for the solution for the infusion vial was diluted in BRB buffer solution $\mathrm{pH} 10.52$ to reach the required concentration. All voltametric analysis methods were performed in triplicate at each concentration.

\section{Apparatus}

A potentiostat (Metrohm Autolab) PGSTAT 204 was used for voltametric determination of ZOL samples. Glassy carbon (GC), gold and platinum were used as the working electrodes in this study, with platinum as the counter electrode and $\mathrm{Ag} / \mathrm{AgCl}$ (3M $\mathrm{KCl}$ ) as the reference electrode.

\section{Statistical analysis}

Several statistical analyses were conducted in the present work according to $\mathrm{ICH}$ guidelines. The statistical analysis included linearity, range, limits of detection and quantitation, and interday and intraday relative standard deviation (RSD), in addition to the recovery study.

\section{RESULTS AND DISCUSSION}

\section{Optimization of voltametric analysis parameters}

Several supporting electrolytes have been studied for voltametric assay of ZOL in a pharmaceutical formulation. The results of supporting electrolyte studies demonstrate the significance of this parameter, since $\mathrm{ZOL}$ did not show electroactivity with several supporting electrolytes, $\mathrm{KNO}_{3} 1.0$ $\mathrm{M}$, phosphate buffer $\mathrm{pH} 6.8$, and sodium citrate buffer $\mathrm{pH}$ 3.0, 
even with different kinds of working electrodes, such as GC, $\mathrm{Pt}$, and $\mathrm{Au}$ electrodes. ZOL exhibited electroactivity when BRB was used as the supporting electrolyte with $\mathrm{pH}$ 5.9410.52 and $G C$ as the working electrode (Figure 2), where BRB buffer of $\mathrm{pH} 10.52$ showed the highest performance. Cyclic voltammograms (CV) of ZOL in (Figure 3) indicated that ZOL is electroactive with an irreversible anodic peak current at $1.48 \mathrm{~V}$.

\section{Voltametric method study}

Three voltametric methods were applied to the ZOL assay in a pharmaceutical formulation: CV, square wave voltammetry (SWV), and differential pulse voltammetry (DPV). ZOL solutions (0.25-1.2 mg. $\mathrm{mL}^{-1}$ ) were studied with BRB buffer, $\mathrm{pH} 10.52$ as the supporting electrolyte and a GC working electrode. An anodic current potential of $1.48 \mathrm{~V}$ was selected for the ZOL assay since it showed the highest correlation between SOL concentration and current in all studied voltametric methods (Table 1, Figure 3-5).

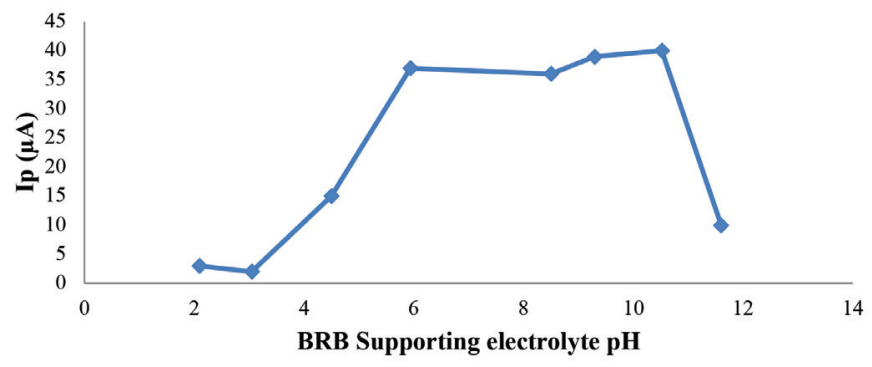

Figure 2. Effect of BRB supporting electrolyte $\mathrm{pH}$ on anodic peak current of cyclic voltametric analysis of ZOL $\left(1.0 \mathrm{mg} \cdot \mathrm{mL}^{-1}\right)$. Scan rate $0.1 \mathrm{~V} . \mathrm{s}^{-1}, \mathrm{GC}$ working electrode

BRB: Britton-Robinson universal buffer, ZOL: Zoledronic acid, GC: Glassy carbon

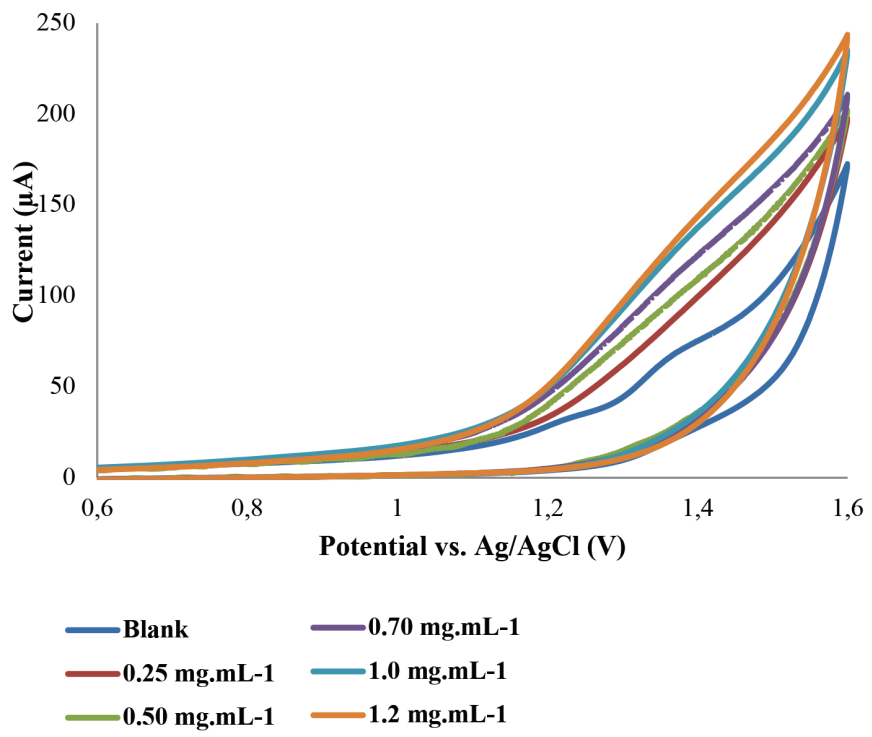

Figure 3. CV study of ZOL (0.25-1.2 mg.mL-1), GC working electrode, BRB $\mathrm{pH} 10.52$ supporting electrolyte, scan rate $0.1 \mathrm{~V} . \mathrm{s}^{-1}$

CV: Cyclic voltammetry, ZOL: Zoledronic acid, BRB: Britton-Robinson universal buffer, GC: Glassy carbon

\section{Linearity and range}

The linearity of the studied voltametric methods was evaluated from the ZOL standard regression line according to $\mathrm{ICH}$ guidelines. Each concentration of ZOL was analyzed in triplicate. According to Table 1, DPV has the highest $\mathrm{R}^{2}$ value of 0.993 compared with other studied methods. The current values plateaued at concentrations higher than $\left(1.2 \mathrm{mg} \cdot \mathrm{mL}^{-1}\right)$ for all studied methods. These results make the dynamic range of DPV and CV (0.20-1.2 mg.mL $\mathrm{mL}^{-1}$ ) and (0.09-1.2 mg. $\left.\mathrm{mL}^{-1}\right)$ for SWV.

\section{Detection and quantitation limits}

The limits of detection and quantitation for voltametric analysis of ZOL were evaluated based on the SD of the blank (BRB buffer of $\mathrm{pH}$ 10.52), where:

Limit of detection $(L O D)=y_{B}+3 S_{B}$ Limit of quantitation $(L O Q)=y_{B}+10 S_{B}$ $\mathrm{S}_{\mathrm{B}}$ : Standard deviation of the blank $\mathrm{y}_{\mathrm{B}:}$ Anodic current response of the blank

According to the results in Table 1, DPV shows the lowest LOD of $37.2 \mu \mathrm{g} \cdot \mathrm{mL}^{-1}$ and SWV the lowest LOQ of $87.5 \mu \mathrm{g} \cdot \mathrm{mL}^{-1}$.

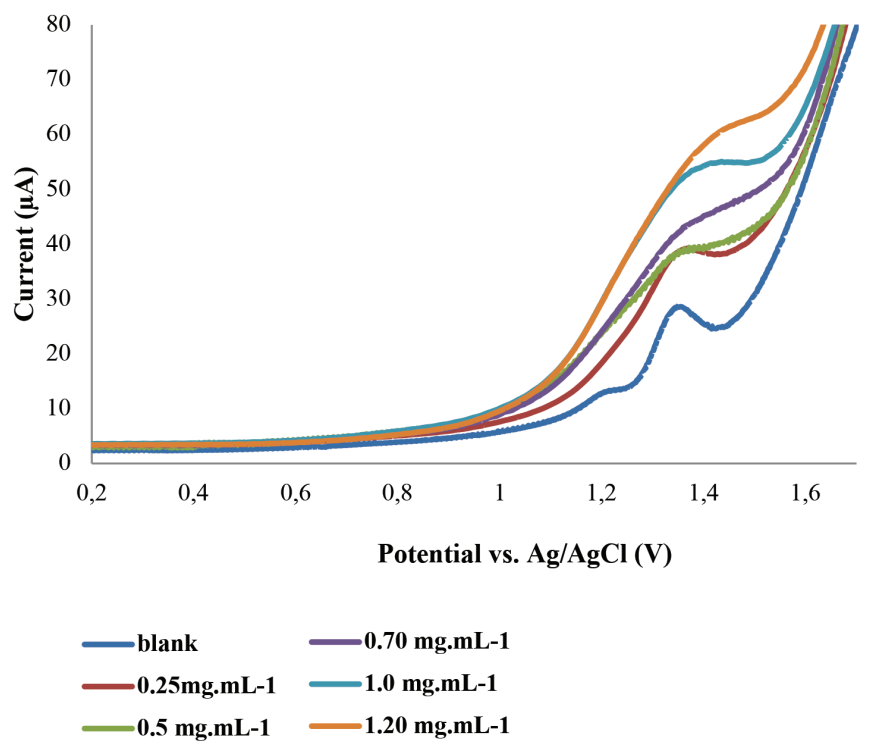

Figure 4. SWV study of ZOL (0.25-1.2 mg.mL-1), GC working electrode, BRB $\mathrm{pH} 10.52$ supporting electrolyte

SWV: Square wave voltammetry, ZOL: Zoledronic acid, GC: Glassy carbon, BRB: Britton-Robinson universal buffer

Table 1. Linearity of ZOL (0.25-1.20 mg. mL-1, BRB pH 10.53) GC electrode

\begin{tabular}{lllll} 
Method & Linear regression & $R^{2}$ & $\begin{array}{l}\text { LOD } \\
\left(\mu g \cdot \mathrm{mL}^{-1}\right)\end{array}$ & $\begin{array}{l}\mathrm{LOQ} \\
\left(\mu \mathrm{g} \cdot \mathrm{mL}^{-1}\right)\end{array}$ \\
\hline $\mathrm{CV}$ & $\mathrm{y}=51.178 x+116.2$ & 0.991 & 84.0 & 196 \\
\hline $\mathrm{DPV}$ & $\mathrm{y}=6.0346 x+12.625$ & 0.993 & 37.2 & 202 \\
\hline SWV & $y=23.935 x+31.843$ & 0.961 & 41.7 & 87.5 \\
\hline
\end{tabular}

ZOL: Zoledronic acid, GC: Glassy carbon, BRB: Britton-Robinson universal buffer, CV: Cyclic voltammetry, DPV: Differential pulse voltammetry, SWV: Square wave voltammetry, LOD: Limit of detection, LOQ: Limit of quantitation 
The slopes of the linear regression calibration curves indicate that CV has the highest sensitivity compared with other methods (Table 1).

\section{Precision}

Each concentration of ZOL was assayed in triplicate. The SD of each point on the calibration curves indicated higher precision at high ZOL concentrations for all studied methods. The repeatability and reproducibility of voltametric analysis of ZOL are shown in (Table 2). All studied voltametric methods showed low intraday and interday RSD, which reflected high precision, where DPV exhibited the highest precision with the lowest RSD values (Table 2 ).

\section{Accuracy}

A commercial preparation of ZOL (ZOL HIKMA ${ }^{\circledR} 4 \mathrm{mg} / 5 \mathrm{~mL}$ ) concentrate for solution for infusion was used to study the accuracy of voltametric methods. Table 3 shows the recovery and RSD of $0.40 \mathrm{mg} \cdot \mathrm{mL}^{-1} \mathrm{ZOL}$ using voltametric methods. DPV shows the best accuracy and precision of $102.32 \%$ recovery and $2.88 \%$ RSD, respectively.

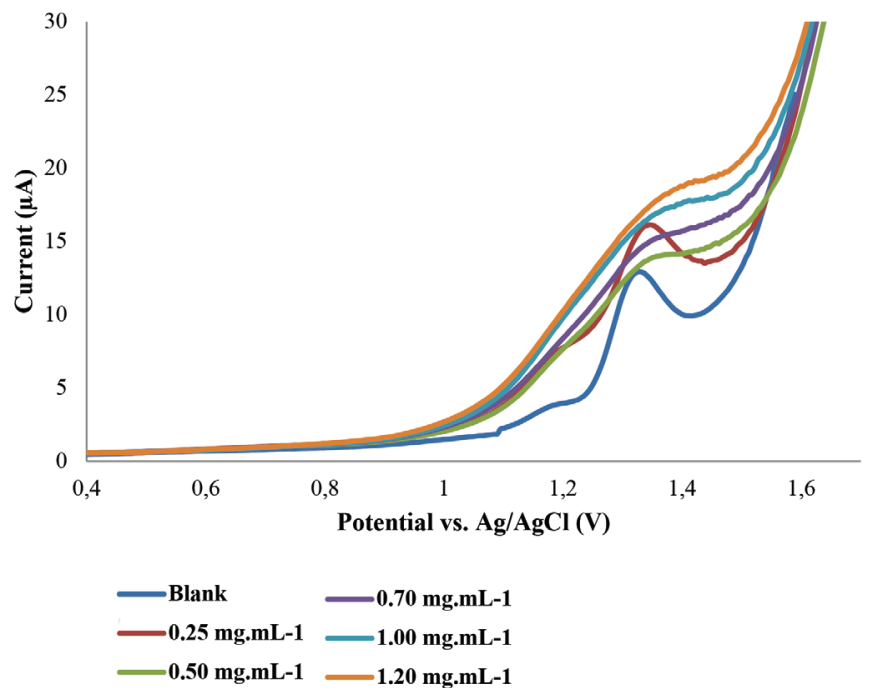

Figure 5. DPV study of ZOL (0.25-1.2 mg.mL-1), GC working electrode, BRB $\mathrm{pH} 10.52$ supporting electrolyte

DPV: Differential pulse voltammetry, ZOL: Zoledronic acid, GC: Glassy carbon, BRB: Britton-Robinson universal buffer

Table 2. Precision of ZOL (1.00 mg.mL-1, BRB pH 10.53) GC electrode

\begin{tabular}{lll} 
Method & Intraday RSD \% & Interday RSD \% \\
\hline CV & 0.476 & 0.652 \\
\hline DPV & 0.286 & 0.344 \\
\hline SWV & 0.733 & 0.854 \\
\hline
\end{tabular}

Intraday RSD \%: Relative standard deviation on the same day of triplicate measurements (repeatability). Interday RSD \%: Three consecutive days' measurements relative standard deviation (reproducibility). ZOL: Zoledronic acid, GC: Glassy carbon, BRB: Britton-Robinson universal buffer, RSD: Relative standard deviation, CV: Cyclic voltammetry, DPV: Differential pulse voltammetry, SWV: Square wave voltammetry
A comparison has been established between different methods used for ZOL determination and the present method according to precision, accuracy and LOD (Table 4). It is clear from Table 4 that most chromatographic methods have better detection limits than those used in the present study. On the other hand, the present study shows comparable recovery and RSD values.

Table 3. Recovery and precision of commercial preparation of ZOL (ZOL HIKMA 4 mg/5 mL) GC electrode (BRB pH 10.53)

\begin{tabular}{lll} 
Method & & $0.40 \mathrm{mg} \cdot \mathrm{mL}^{-1}$ \\
\hline \multirow{2}{*}{ CV } & Found \pm SD & $0.3874 \pm 0.0158$ \\
\cline { 2 - 3 } & Recovery \% & 96.86 \\
\cline { 2 - 3 } & RSD \% & 4.08 \\
\hline \multirow{3}{*}{ DPV } & Found \pm SD & $0.4092 \pm 0.0117$ \\
\cline { 2 - 3 } & Recovery \% & 102.32 \\
\cline { 2 - 3 } & RSD \% & 2.88 \\
\hline \multirow{3}{*}{ SWV } & Found \pm SD & $0.4162 \pm 0.0144$ \\
\cline { 2 - 3 } & Recovery \% & 104.06 \\
\cline { 2 - 3 } & RSD \% & 3.46 \\
\hline
\end{tabular}

Recovery: Obtained ZOL/added ZOL *100\%. ZOL: Zoledronic acid, GC: Glassy carbon, BRB: Britton-Robinson universal buffer, CV: Cyclic voltammetry, DPV: Differential pulse voltammetry, SWV: Square wave voltammetry, RSD: Relative standard deviation, SD: Standard deviation

Table 4. Comparison of detection limit, precision, and recovery for determination of zoledronic acid between the present work and other used methods

\begin{tabular}{llll} 
Method & LOD & Precision & Recovery \\
\hline $\begin{array}{lll}\text { RP-HPLC } \\
\text { UV detector }\end{array}$ & $0.04 \mu \mathrm{g} \cdot \mathrm{mL}^{-1}$ & $2.5 \%$ & $101 \%$
\end{tabular}

RP-HPLC

evaporative light scattering

$0.9 \mu \mathrm{g} \cdot \mathrm{mL}^{-1} \quad 0.4 \%-0.8 \%$

$98 \%-102 \%$ detection ${ }^{10}$

HPLC-

tandem mass $\quad 3.4 \mathrm{ng} \cdot \mathrm{mL}^{-1} \quad 0.52 \%-8.7 \% \quad 97 \%-101.9 \%$ spectrometry ${ }^{12}$

RP-HPLC

Hydroxyapatite- 200 mg.mL-1 $\quad 0.32 \%-115 \% \quad 99.01 \%$ based $\quad 200 \mu \mathrm{g} \cdot \mathrm{mL}^{-1} \quad 0.32 \%-1.15 \% \quad 100.8 \%$

Nanoparticles ${ }^{13}$

Switchable

fluorescence $\quad 0.011 \mu \mathrm{g} \cdot \mathrm{mL}^{-1} \quad 2.70 \% \quad 92.2 \%-104.0 \%$ probe $^{16}$

DPV, GC

$\begin{array}{llll}\text { electrode } \quad 37.2 \mu \mathrm{g} \cdot \mathrm{mL}^{-1} & 0.286 \%-0.344 \% & 102.32 \%\end{array}$

(present work)

RP-HPLC: Reversed-phase high-performance liquid chromatography, UV: Ultraviolet, DPV: Differential pulse voltammetry, GC: Glassy carbon, LOD: Limit of detection 


\section{CONCLUSION}

Voltametric analysis indicated that $\mathrm{ZOL}$ is an electroactive compound. CV of ZOL exhibited an irreversible anodic peak current at $1.48 \mathrm{~V}$. Optimization of voltametric analysis parameters indicated the significance of the supporting electrolyte $\mathrm{pH}$ and the type of working electrode. CV, SWV, and DPV have been applied for voltametric analysis of ZOL, But DPV is the recommended method for voltametric analysis of ZOL because of its high-performance regarding accuracy, precision, and LOD compared with other studied methods.

Conflicts of interest: No conflict of interest was declared by the authors. The authors alone are responsible for the content and writing of the paper.

\section{REFERENCES}

1. Khajuria DK, Razdan R, Mahapatra DR. Drugs for the management of osteoporosis: a review. Rev Bras Reumatol. 2011;51:365-382.

2. Khajuria DK, Disha C, Razdan R, Mahapatra DR. Comparative evaluation of zoledronic acid, alfacalcidol, and propranolol in pharmacological correction of experimental osteoporosis. Lat Am J Pharm. 2013;32:968976.

3. Khajuria DK, Disha C, Razdan R, Mahapatra DR, Vasireddi R. Prophylactic effects of propranolol versus standard therapy on a new model of disuse osteoporosis in rats. Sci Pharm. 2014;82:357-374.

4. Siddique MR, Alothman, ZA, Rahman N. Analytical techniques in pharmaceutical analysis: a review. Arab J Chem. 2017;10:S1409-S14021.

5. Gupta VK, Rajeev J, Keisham R, Nimisha J, Shilpi A. Voltammetric techniques for the assay of pharmaceuticals-a review. Anal Biochem. 2011;408:179-196.

6. Fedder M, Amro A, Bin Oun S, Ratrout S, Asfour F. Voltammetric Determination of Glycopyrrolate in a pharmaceutical formulation. Turk J Chem. 2018;42:1736-1743.

7. Amro A. Voltammetric determination of prifinium bromide in a pharmaceutical formulation. J Taibah Univ Sci. 2019;13:1158-1162.
8. Amro A. Voltammetric method development for itopride assay in a pharmaceutical formulation. Curr Pharm Anal. 2020;16:312-318.

9. Reddy LM, Reddy KJ, Reddy PR. A simple RP-HPLC method for related substances of zoledronic acid in pharmaceutical products. Arab J Chem. 2017;10:S196-S204

10. Burmaoglu RE, Aslan SS. Determination of zoledronic acid and its related substances by high performance liquid chromatography with evaporative light scattering detection. J Chromatogr Sci. 2019;57:33-43.

11. Veldboer K, Vielhaber T, Ahrens H, Hardes J, Streitburger A, Karst U. Determination of zoledronic acid in human urine and blood plasma using liquid chromatography/electrospray mass spectrometry. J Chromatogr B Biomed Appl. 2011;879:2073-2080.

12. Fabrizio A, Faro L, Giorgetti R, Busardò FP, Lodi G, Martini V, Pispero A, Iriti M, Varoni EM. Development and validation of a method using ultra performance liquid chromatography coupled to tandem mass spectrometry for determination of zoledronic acid concentration in human bone. J Pharm Biomed Anal. 2019;162:286-290.

13. Khajuria DK, Razdan R. Sensitive and rapid RP-HPLC quantification of zoledronic acid in a hydroxyapatite -based nanoparticles. Indian J Pharm Sci. 2017;79:553-558.

14. Raccor BS, Sun J, Lawrence RF, Li L, Zhang H, Somerman MJ, Totah RA. Quantitation of zoledronic acid in murine bone by liquid chromatography coupled with tandem mass spectrometry. J Chromatogr B Biomed Appl. 2013;935:54-60.

15. Legay F, Gauron S, Deckert F, Gosset G, Pfaar U, Ravera C, Wiegand $H$, Schran $H$. Development and validation of a highly sensitive RIA for zoledronic acid, a new potent heterocyclic bisphosphonate, in human serum, plasma and urine. J Pharm Biomed Anal. 2002;30:897-911.

16. Amin N, Afkhami A, Hosseinzadeh L, Madrakian T. Green and costeffective synthesis of carbon dots from date kernel and their application as a novel switchable fluorescence probe for sensitive assay of Zoledronic acid drug in human serum and cellular imaging. Anal Chim Acta. 2018;1030:183-193. 